\title{
両親媒性高分子電解質の会合構造と溶液物性 \\ Association Structures of Amphiphilic Polyelectrolytes and Their Solution Properties
}

遊佐真一
兵庫県立大学大学院 工学研究科
T671-2201 兵庫県姬路市書写 2167
Shin-ichi YUSA
Graduate School of Engineering,
University of Hyogo
2167 Shosha, Himeji,
Hyogo 671-2201, JAPAN
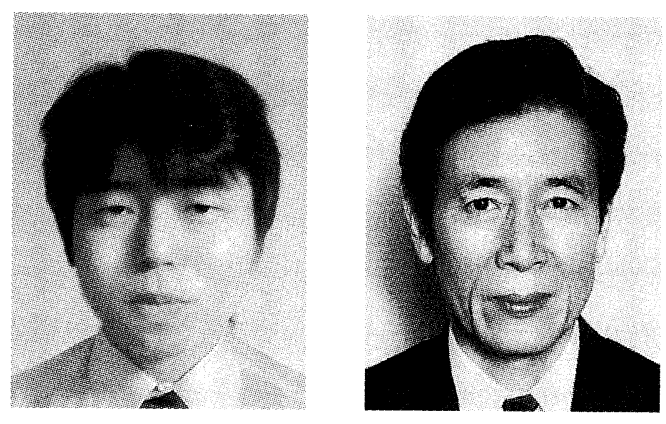

森島洋太郎

福井工業大学 工学部

T910-8505 福井県福井市学園 6-3-1

Yotaro MORISHIMA

Faculty of Engineering,

Fukui University of Technology

6-3-1 Gakuen, Fukui 910-8505, JAPAN

論文要旨：両親媒性高分子電解質は水中で, 疎水基間の会合により多様な組織体を形成する。形成される 組織体の構造は踈水基と親水基の化学構造, 両者の組成比と配列, 高分子主鎖との結合様式など, 高分子の 化学構造に大きく依存する。このような両親媒性高分子電解質により形成される凝集組織体のレオロジー的 な性質は, 凝集体の構造, 形態, 大きさなどによって決まり, これらは踈水基の会合が同一ポリマー内で起 こるか，ポリマー間で起こるか，あるいはその両者が同時に起こるかにより大きく異なる。また近年，両親 媒性高分子電解質の分子設計により, 水中で形成される凝集組織体に刺激応答性を付与することが可能に なった。たとえば, $\mathrm{pH}$ 変化をトリガーとする高分子ミセルの形成や解離を制御できるブロック共重合体など が知られている。

\begin{abstract}
Amphiphilic polyelectrolytes or hydrophobically modified polyelectrolytes undergo hydrophobically driven self-association in aqueous media to form, in some cases, well-defined spatial structures on a nanometer scale (nanostructures). This depends strongly on their macromolecular architectures. This review is concerned with recent advances in the studies of amphiphilic block and random polyelectrolytes, including fundamental aspects of the self-association of amphiphilic polyelectrolytes. Extensive studies by a large number of research groups have so far yielded a good deal of progress in the fundamental understanding of underlying structure-property relationships in the self-association of amphiphilic polyelectrolytes in aqueous media. This review particularly focuses on solution properties of some amphiphilic polyelectrolytes that exhibit stimuli-responsiveness, which may find applications in various commercial products.
\end{abstract}

Key words: Amphiphilic Polyelectrolyte, Self-Organization, Hydrophobic Interaction, Unimolecular Micelle, Stimuli-Responsive Polymer

\section{1 はじめに}

一般的に，踈水基で化学修飾した高分子電解質，すな わち両親媒性高分子電解質は，その化学構造によっては 水中で疎水基間の会合により幾何学的に整った形状を 持った高分子会合体を形成する。このような会合体は, 通常ナノメートルスケールの大きさを有することから， 「高分子ナノ組織体」あるいは「高分子ナノ構造体」と 呼ばれる。また高分子が自発的にナノ組織体を形成する

\section{連絡者：遊佐真一}

E-mail : yusa@eng.u-hyogo.ac.jp
現象を「自己組織化」と呼ぶ。

水中に扔ける両親媒性高分子電解質の自己組織化現象 は水が選択溶媒として働き, 疎水性相互作用による疎水 基の会合と, 電解質連鎖の水への微視的な溶解抢よび, それに伴う排除体積効果によって起こる一種のミクロ相 分離現象である。疎水基会合によって生じたミクロドメ インは, その外側を囲む電解質連鎖によって水との親和 性が保たれるが, 高分子会合体は常に均一で透明な溶液 状態を示すとは限らず，物理ゲルの形成や巨視的な相分 離を起こす場合もある。また，このような高分子組織体 の水溶液のレオロジー的な性質は会合体の構造, 形態, 
大きさなどによって決まる。これらは疎水基の会合が同 一ポリマー内で起こるか，ポリマー間で起こるか，ある いはその両者が同時に起こるかにより大きく異なる。

両親媒性高分子電解質の自己組織化挙動はポリマー自 体の化学構造だけでなく, 温度, $\mathrm{pH}$, イオン強度, 化 学物質の添加などの外的な条件にも影響される場合があ る。外部刺激に敏感に応答して会合状態が大きく変化す る両親媒性高分子電解質は, 薬物送達システム (DDS), 環境センサー，分離技術などの応用につながる期待があ ることから, 近年, 刺激応答性の両親媒性高分子電解質 には特に多くの関心が集まっている。

\section{2 両親媒性ポリマーの会合様式}

疎水性高分子連鎖（B ブロック）の片末端または両末 端に親水性高分子連鎖（A ブロック）が結合した $\mathrm{AB}$ ま たは ABA 型ブロック共重合体は, Fig. 1 に示すように 疎水性連鎖が多分子的に集合して疎水性のコアを形成 し，その外側に親水性連鎖が放射状に伸びたコアーコロ ナ型の球状ミセルを形成する。高分子の会合数は, 低分 子界面活性剂ミセルの場合と同様に, あるせまい範囲の 值をとり, 臨界ミセル濃度 $(\mathrm{cmc})$ が存在する。このよ うな会合様式は「閉じた会合」と呼ばれている ${ }^{1-3)}$ 。

複数の疎水性連鎖が高分子鎖上で親水性連鎖に隔てら れて結合しているマルチブロック共重合体やランダム共 重合体の場合には, 疎水性連鎖間の会合が多分子的に起 こると，会合は無制限に大きくなり巨視的な相分離やゲ ル化を起こす（Fig. 2）。このような会合様式は「開いた 会合」と呼ばれる。会合性の強い疎水性連鎖を少量ラン ダムに結合した高分子電解質では，分子間の「開いた会 合」が起こりやすい。このような性質のポリマーは会合 性増粘剂として実用に供されている。一方，疎水性連鎖 の会合が同一ポリマー鎖内のみに限定された「閉じた会 合」が起こると単一の高分子鎖からなるミセル状の組織 体が形成される（Fig. 2)。この会合体は疎水基の会合に より形成されたコアのまわりを親水性連鎖のループが花 びら状に取り囲んでいるので, フラワーミセルと呼ばれ る。フラワーミセルの水溶液では粘度増加は観測されな w。

\section{3 会合性増粘剈としての両親媒性高分子電解質}

会合性の強い踈水基を少量ランダムに結合した水溶性 ポリマーは著しい増粘効果を示すことから，会合性増粘 剂（associative thickener：AT）として，広く寒用に供 されている。AT ポリマーに扔いては，分子間の疎水基 会合部が高分子鎖の架橋点として働くが，このような架 橋点は弱い「物理架橋」であるため, 水溶液は著しい shear thickening や thinning など, 架橋点の動的な性質 に基づいた，特徴的な粘度挙動を示す。一般に，ポリ マー濃度の増加に従って溶液粘度は顕著に増加し, やが て溶液はゲル化する。親水基が電解質の場合には, 著し い増粘効果だけでなく，良好な分散効果を示す。例え ば，少量の AT 電解質ポリマーを添加することにより安 定な $\mathrm{O} / \mathrm{W}$ 型エマルジョンを調製することができる。水 相において疎水基間での会合により網目構造を形成する と共に，一部の疎水基は油滴にアンカーとして入り达み 油滴を網目の中に取り込むことが安定化の理由である。

一般的に希薄溶液中では分子内会合が優先しても, 準 希薄または濃厚領域ではポリマー間の会合に移行するの が通常である。また親水性ポリマー中への疎水基の導入 量が少ない方がポリマー分子間での会合性は大きくな る。疎水基含量が増加すると, 同一のポリマー内で疎水 基会合が優先して起こり，ポリマー鎖は収縮して，より 一層ポリマー内での会合に有利にはたらく。したがっ て，ATポリマーの設計には，できるだけ会合性の強い 疎水基を少量ポリマー中に導入することが重要である。 実際，分子量の高い親水性ポリマーに分子サイズの大き な疎水性残基を少量導入したタイプのポリマーが優れた

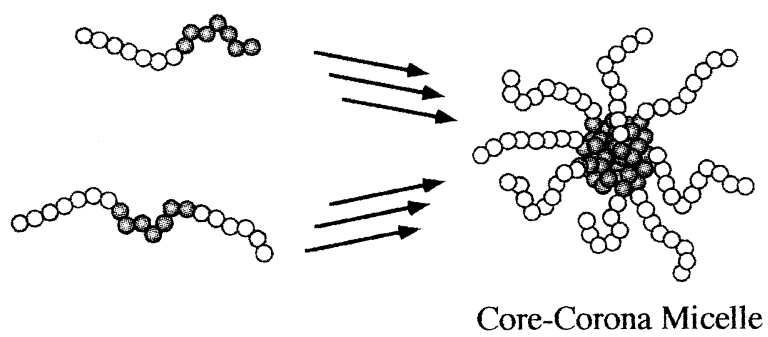

Fig. 1 Conceptual Illustration of Interpolymer Closed Association of AB Diblock and ABA Triblock Copolymers. $\bigcirc$ : Hydrophilic unit $(\mathrm{A})$ and hydrophobic unit (B).

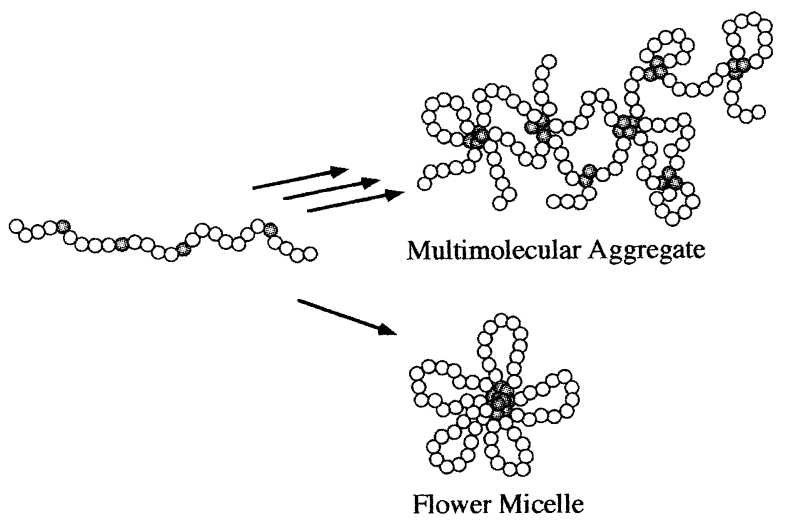

Fig. 2 Conceptual Illustration of Interpolymer Open Association and Intra Polymer Closed Association of $A B$ Random Copolymers. $\bigcirc$ : Hydrophilic unit (A) and $\mathbf{O}$ : hydrophobic unit (B). 
ATポリマーとして用いられている。

疎水基をフレキシブルな親水性のポリオキシエチレン (POE) スペーサーを介して主鎖から離して結合すると, 疎水基の主鎖による束縛が緩和されるために，大きな疎 水性ドメインが形成される。アルキル基 $\left(\mathrm{C}_{12}\right)$ を有する $\operatorname{POE}\left(\mathrm{E}_{m}\right)$ 系中性界面活性剤 $\left(\mathrm{C}_{12} \mathrm{E}_{m}\right)$ を側鎖結合したモ ノマー（「界面活性剤モノマー」(surfmer）と呼ばれる) と2-アクリルアミド-2-メチルプロパンスルホン酸のナ トリウム塩(AMPS) のランダム共重合体は（Fig. 3）, POE 鎖を介してアルキル基を主鎖に結合した，一種の 両親媒性高分子電解質である ${ }^{4-6)}$ 。POE 鎖の重合度 $m$ が 6 以上になると, 側鎖結合した界面活性剂のミセル形成 に及ぼすポリマー主鎖の立体的な阻害効果がなくなり， フリーの界面活性剤が形成するミセルとほぼ同じ会合数 の $\mathrm{C}_{12}$ ドメインが形成される。ポリマー側鎖で形成する ミセルは同一および異なった高分子鎖上の界面活性剂残 基の会合によるため，ミセルを介して高分子鎖は物理的 に架橋され, 高濃度領域では網目構造を形成する。この ようなミセルによる架橋は外部刺激に応答して変化する

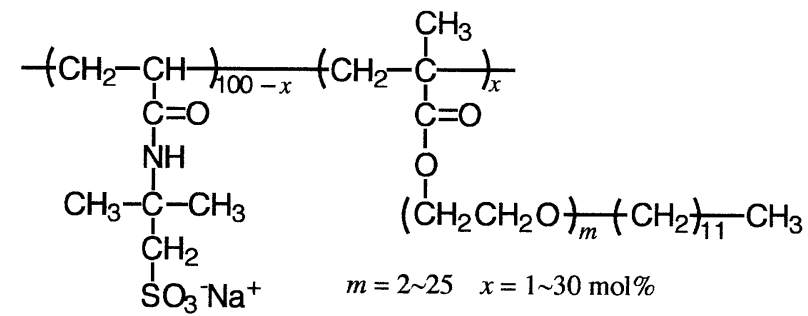

Fig. 3 Chemical Structure of Random Copolymer of AMPS and Methacrylates Substituted with Ethylene Oxide Based Surfactant Moieties.

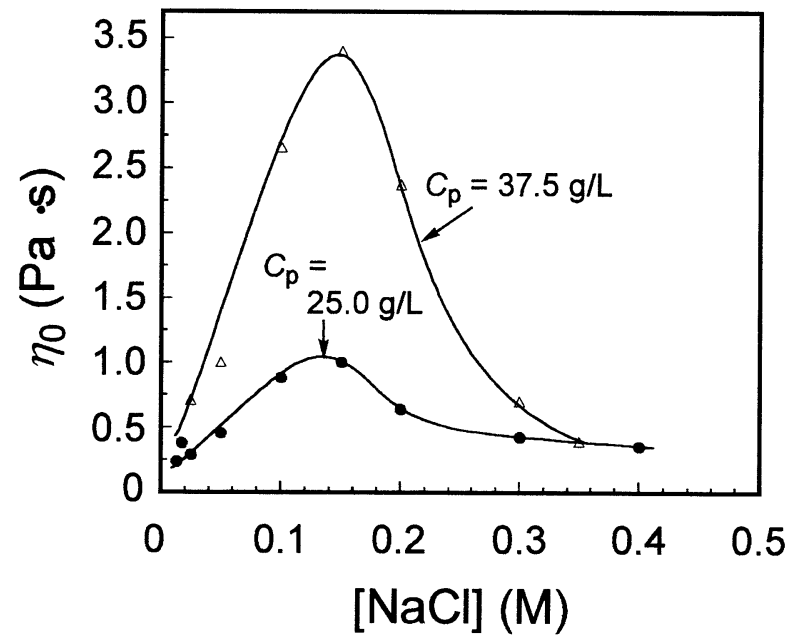

Fig. 4 Dependence of Steady-shear Viscosity for a Random Copolymer of AMPS and a Methacrylate Substituted with $\mathrm{C}_{12} \mathrm{E}_{25}(x=20 \mathrm{~mol} \%)$ on the Concentration of Added Salt at Polymer Concentrations $\left(C_{\mathrm{p}}\right)$ of 25.0 and $37.5 \mathrm{~g} / \mathrm{L}$ in Water.
動的な架橋として振る舞う。たとえば, イオン強度, 温 度, $\mathrm{pH}$, ずり応力に敏感に応答して顕著な粘度変化や ゲル化を起こす。食塩を添加してイオン強度を変化させ た場合の溶液粘度への影響の一例を Fig. 4 に示す ${ }^{4)}$ 。困 に見られるように，添加塩濃度に対して粘度が極大值を 示すが，これは以下の理由による。側鎖結合された界面 活性剂残基 $\mathrm{C}_{12} \mathrm{E}_{25}$ の会合はポリアニオンの静電反発を凌 駕して起こるため, 溶液のイオン強度の増加に従って, 高分子間での $\mathrm{C}_{12} \mathrm{E}_{25}$ 基の会合によるミセル形成が有利に なる。従って, 溶液粘度はイオン強度の増加に従って増 加するが，イオン強度をさらに増加させると，高分子内 でのミセル形成が有利になり粘度は減少する。

\section{4 ユニマーミセル}

シクロドデシル $(\mathrm{Cd})$ 基およびアダマンチル $(\mathrm{Ad})$ 基の ように，環状の疎水基で $N$-位を置換したメタクリルア ミドと AMPS のランダム共重合体の両親媒性高分子電 解質（Fig. 5）は水中で，踈水基会合が分子内で優先し て起こり，ほぼ完全な分子内自己組織化を起こす ${ }^{7-10)}$ 。 疎水基含量が $10 \mathrm{~mol} \%$ 以下の場合，ポリマーは通常の高 分子電解質と同様，電荷セグメント間の静電反発により 伸びたコンホメーションをとる（Fig. 6(a)）。疎水基含 量が 10 〜 $30 \mathrm{~mol} \%$ に増加すると，電荷セグメント間の 反発に打ち勝って，同一ポリマー鎖の近接疎水基間で会 合して，分子鎖に沿って Fig. 6(b) のような疎水性ミク ロドメインがいくつもできる。この疎水性ミクロドメイ ンはループ状の電荷セグメントに取り囲まれているの で，局所的に見るとフラワーミセル構造になっている。 疎水基含量が $30 \mathrm{~mol} \%$ より多くなると, フラワーミセル
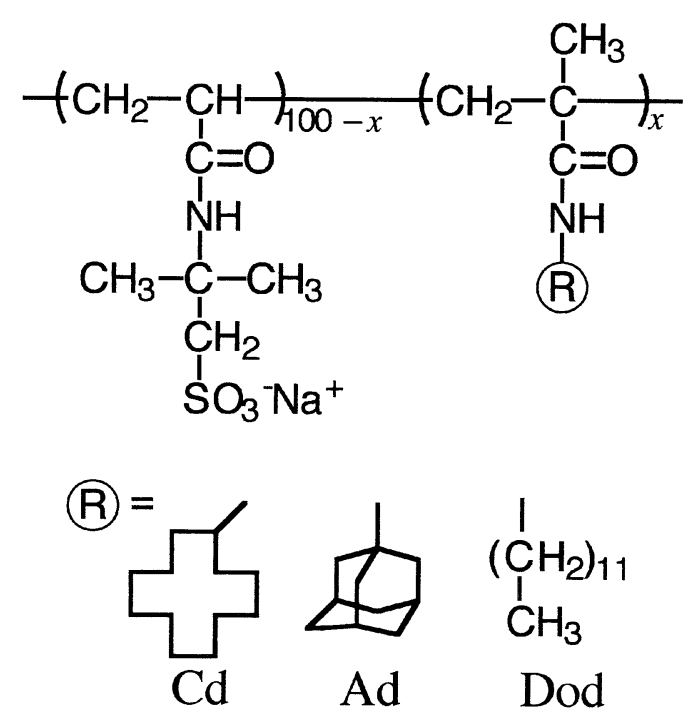

Fig. 5 Chemical Structure of Poly(AMPS/Cd), Poly(AMPS/Ad), and Poly(AMPS/Dod). 
(a)

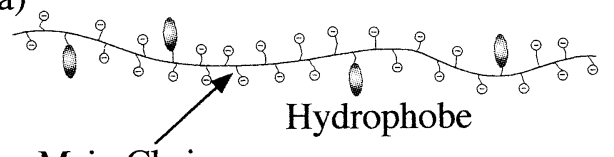

Main Chain

Hydrophobe

(b)

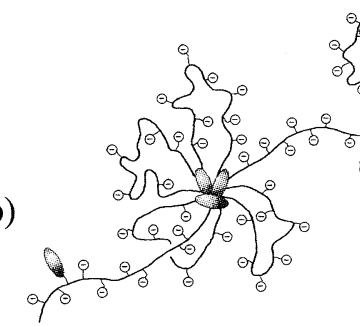

(c)

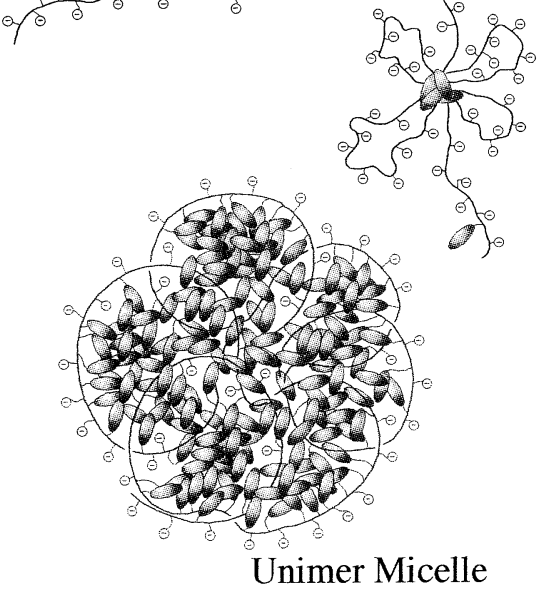

Fig. 6 Conceptual Illustration of Self-Organization of Poly(AMPS/Cd) and Poly(AMPS/Ad) in Water. (a) The hydrophobe content $<10 \mathrm{~mol} \%$, (b) 10 $30 \mathrm{~mol} \%$, and (c) $>30 \mathrm{~mol} \%$.

のコアである疎水性ミクロドメインが大きくなり，電荷 セグメントのループのサイズは小さくなるので，フラ ワーミセル構造を維持できなくなり，疎水性コアは，同 一ポリマー鎖内で 2 次的に会合を起こす。その結果，ポ リマー主鎖は高度に折り䪶まれて, 3 次構造からなる球 状のユニマーミセル（Fig. 6 (c)）を形成して安定化す る。このユニマーミセルの構造はリゾチームなどのよう な 1 本鎖のポリペプチドが形成する球状タンパク質の空 間構造に酷似している。すなわち球状タンパク質の場 合, 疎水性アミノ酸残基は内部に包み込まれ, 親水性ア ミノ酸残基が表面に配置されることによって水に溶解す るが，ユニマーミセルの場合も踈水基を内側に向け, 親 水基であるスルホネート基をミセル表面に配置すること で水溶性が保たれている。また通常の低分子の界面活性 剤は $\mathrm{cmc}$ 以下の濃度でミセルは形成されないが，ユニ マーミセルは単一の高分子鎖から形成されているので, ポリマー濃度がどんなに低くてもミセル構造が維持され る。一般的に両親媒性高分子電解質の濃度を増加させる と，ポリマー間での会合が起こるが，ユニマーミセルの 場合は濃度増加によるポリマー間の会合は全く起こら ず，シクロドデシル基を含むポリマーの場合，動的光散
乱測定から求めた流体力学的半径は濃度に依存せずに $5.5 \mathrm{~nm}$ であった。また，ポリマー主鎖と側鎖を結合して いるアミド基に由来する赤外吸収スペクトルは著しく低 波数側へシフトしていることから，ユニマーミセル構造 にはアミド基間の水素結合が大きく関与していると考え られる。

環状のシクロドデシル基と同じ炭素数である直鎖状の ドデシル (Dod) 基を含むメタクリルアミドと AMPS の ランダム共重合体の場合（Fig. 5）はシクロドデシル基 と比べて，ルーズなユニマーミセルを形成することがプ ロトン NMRの緩和時間測定から明らかにされてい る $^{10.11)}$ 。このことはシクロドデシル基が形成する会合組 織体に封じ込められたアゾベンゼンの光異性化が，ドデ シル基の会合組織体中に比べて著しく抑制されることか らも示されている ${ }^{11}$ 。

\section{$5 \mathrm{pH}$ 応答性ユニマーミセル}

ユニマーミセルは，その内部の疎水性ミクロドメイン 内に，さまざまな蹯水性の低分子化合物を取り込むが， ユニマーミセルの構造が安定なため，一旦取り达まれた 低分子化合物を外部に取り出すことは困難である。もし 適当な外部刺激によりユニマーミセルの形成と崩壊を自 在に制御できれば，疎水性ドメイン内部に取り込ませて いた薬物などを外部刺激により，水相へ放出させること が可能となる。このような刺激応答型インテリジェン ト・ユニマーミセルはDDS などへの応用が期待される。 外部刺激としては，温度， $\mathrm{pH}$, 光, 添加する化学物質 の種類や量などさまざまなものが考えられる。Fig. 7 に 示す AMPS と脂肪酸を側鎖結合したアクリルアミド型 のモノマーである11-アクリルアミドウンデカン酸ナト リウムを $50 \mathrm{~mol} \%$ 含むランダム共重合体は, $\mathrm{pH}$ に応答 するユニマーミセルを形成する ${ }^{12,13)}$ 。このポリマーは酸 性の水溶液中で, 側鎖脂肪酸のカルボキシレートイオン が選択的にプロトン化されることで，疎水性が増加して ユニマーミセルを形成する。また，ポリマーの水溶液を 塩基性にすると，カルボン酸が脱プロトン化されて生じ

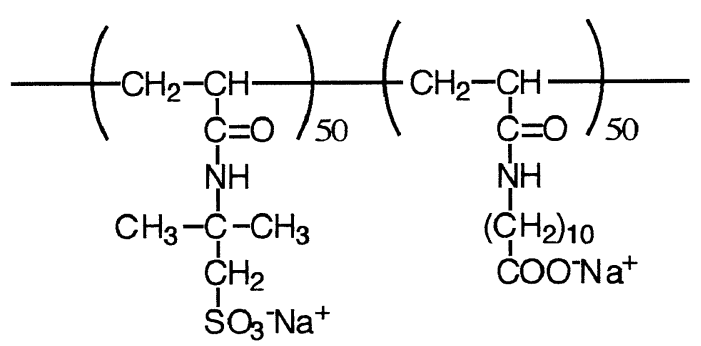

Fig. 7 Chemical Structure of pH-Responsive Random Copolymer. 
るカルボキシレートイオン間の静電反発がアルキル基の 疎水性相互作用を凌駕するので，ユニマーミセルは崩壊 してポリマー鎖は伸びたコンホメーションに変化する (Fig. 8)。

水溶液の $\mathrm{pH}$ によるポリマーのコンホメーション変化 は流体力学的半径に反映される。Fig. 9 に動的光散乱測 定によって求めた流体力学的半径と $\mathrm{pH}$ の関係を示す。 酸性領域で粒径の減少が観測されているが，これは選択 的にプロトン化されたポリマー側鎖の脂肪酸の疎水性相 互作用による分子内自己会合によりコンパクトなユニ マーミセルが形成されるためである。一方，中性〜塩基 性領域では脱プロトン化されたカルボキシレートイオン 間の静電反発がアルキル基の疎水性相互作用を凌駕する ことで，ポリマー鎖がコンパクトな形態から伸びた形態 に変化するので粒径の増加が観測されている。

酸性の水溶液中において，ユニマーミセルの疎水性ド メイン中に，疎水性の低分子化合物を取り込めることが ピレンを用いた実験により示されている。疎水性蛍光プ ローブであるピレンの蛍光スペクトルは，そのまわりの 媒体の微極性を反映し, 極性が低くなると蛍光スペクト ルにおける第 1 振動ピーク強度に対する第 3 振動ピーク

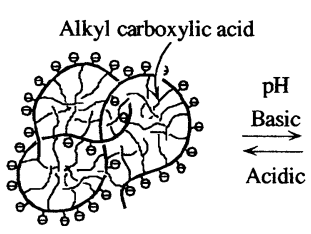

Unimer micelle

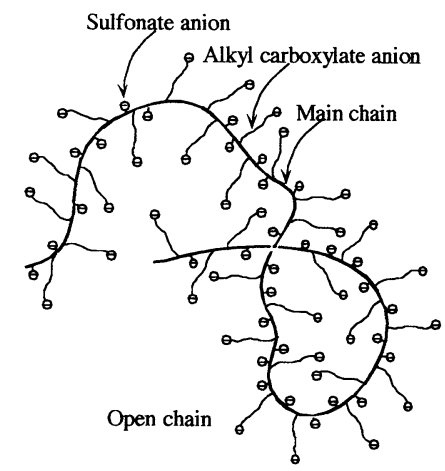

Fig. 8 Schematic Representation of pH-Induced Formation and Disruption of a Unimer Micelle of the Copolymer.

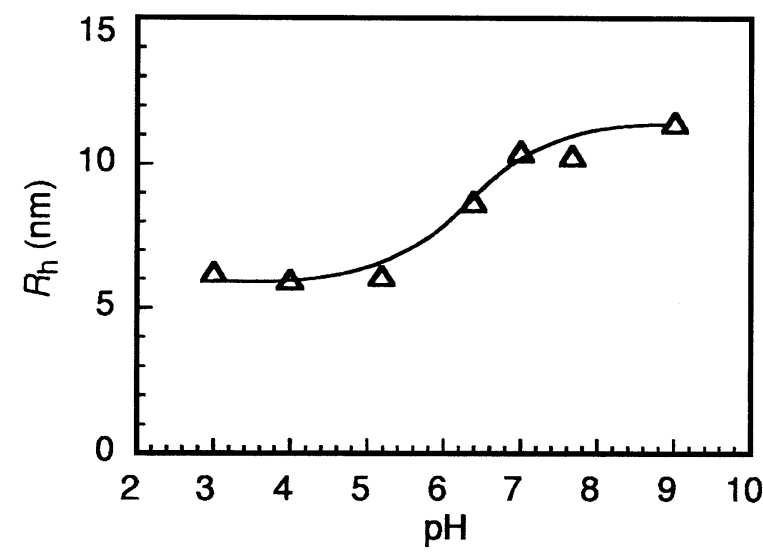

Fig. 9 Hydrodynamic Radius $\left(R_{\mathrm{h}}\right)$ for the Copolymer as a Function of $\mathrm{pH}$ in $0.1 \mathrm{M} \mathrm{NaCl}$.

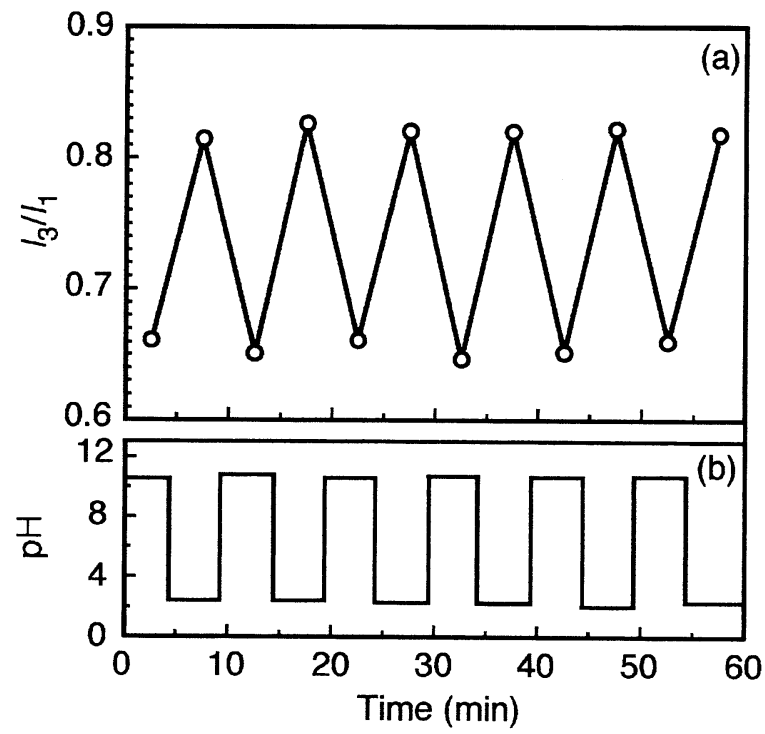

Fig. 10 Pyrene Fluorescence in the Presence of the Copolymer at Acidic and Basic Conditions Switched with a 5 Minute Cycle. (a) $I_{3} / I_{1}$ in pyrene fluorescence spectra as a function of measurement time. (b) $\mathrm{pH}$ as a function of measurement time.

強度の比（ $I_{3} / I_{1}$ の值）が大きくなることが知られてい る ${ }^{14)}$ 。ピレンとポリマーを溶解した水溶液で, 各 $\mathrm{pH} に$ おけるピレンの $I_{3} / I_{1}$ を測定すると，酸性領域において $I_{3} / I_{1}$ の増加が観測され，塩基性領域では減少が観測され る。これは酸性領域でポリマーはユニマーミセルを形成 し, その疎水性ドメイン内部にピレンを取り込むことが 可能であり，塩基性領域ではユニマーミセルが崩壊する ので，ピレンは水相に放出されることを示している。こ のような $\mathrm{pH}$ 変化をトリガーとした，ピレンの取込みと 放出は，くり返し行うことができる。Fig. 10 はピレンと ポリマーを溶解した水溶液で， $\mathrm{pH}$ を塩基性と酸性との 間で約 5 分間隔で連続的にくり返し調製した時のピレン の $I_{3} / I_{1}$ の変化を示している。Fig. $10(\mathrm{a})$ のプロットは 測定時間に対する $I_{3} / I_{1}$ の変化で, Fig. $10(\mathrm{~b})$ は測定時 間に対してどのように $\mathrm{pH}$ を調製したかを示している。 溶液の $\mathrm{pH}$ の変化に応じて $I_{3} / I_{1}$ は酸性側で約 0.82 で, ユニマーミセルの疎水性ドメイン内部にピレンが取り込 まれていることがわかる。一方，塩基性側では $I_{3} / I_{1}$ は 約 0.65 で，ユニマーミセル内部に取り込まれていたピレ ンは水相に放出されている。またユニマーミセル内部に 取り込まれた疎水性化合物は，水溶液の $\mathrm{pH}$ を塩基性に しない限り数日間にわたって安定に保持される。

\section{6 外部刺激に応答するブロック共重合体}

親水性の $\mathrm{A}$ ブロックと, $\mathrm{pH}$ や温度など外部刺激によ り，親水性または疎水性に性質の変化する B ブロックか 
らなる $\mathrm{AB}$ 型ブロック共重合体の場合，両ブロックが親 水性なら単一高分子であるユニマー状態として水に溶解 するが，外部刺激に応答する B ブロックが疎水性に変化 すると，通常の両親媒性ブロック共重合体と同様に cmc 以上で高分子ミセルを形成する（Fig. 11）。このような 外部刺激に応答して可逆的に会合と解離を行うことが可 能な水溶性のブロック共重合体は新規デリバリーシステ ムや環境センサーなど，さまざまな応用が期待されてい $る^{15,16)}$ 。可逆的付加一開裂連鎖移動（RAFT）型の“リビ ング”ラジカル重合法 ${ }^{17,18)}$ を利用することにより，外部 刺激に応答して会合と解離を起こす $\mathrm{AB}$ 型ブロック共重 合体が合成されている。たとえばスルホネート基を側鎖 結合した AMPS ブロックと，カルボキシレート基を側 鎖結合した 6-アクリルアミドヘキサン酸ナトリウム ( $\mathrm{AaH})$ ブロックからなるブロック共重合体（Fig. 12） の場合，スルホネートイオンを含むブロックは $\mathrm{pH}$ に影 響されずに水溶性であるが，カルボキシレート基を含む ブロックはアルカリ性では水溶性だが，弱酸性ではプロ トン化されて疎水性に変化する ${ }^{19)}$ 。したがって，この $\mathrm{AB}$ 型ブロック共重合体は，アルカリ性では完全に水に 溶解してユニマー状態で存在するが，弱酸性では $\mathrm{AaH}$ ブロックを疎水性コア，AMPS ブロックを親水性コロナ とするコアーコロナ型の高分子ミセルが形成されること

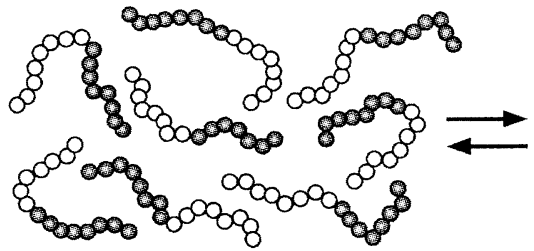

Unimer

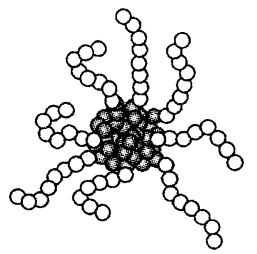

Micelle
Fig. 11 Schematic Representation of Stimuli-Induced Formation and Disruption of a Core-Corona Micelle of Block Copolymers.

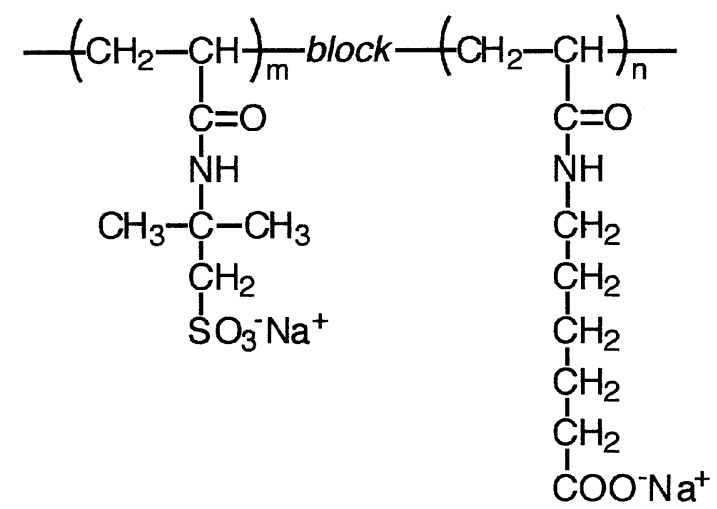

Fig. 12 Chemical Structure of Block Copolymer with AMPS and Sodium 6-Acrylamidohexanoate (AaH).
が，動的光散乱から調べた粒径および ${ }^{1} \mathrm{H}$ NMR の緩和 時間の $\mathrm{pH}$ 依存性から示された。

ポリ（N-イソプロピルアクリルアミド）（PNIPAM） は室温では水に溶解するが，下限臨界溶液温度（LCST） 以上の温度になると，分子が凝集して水溶液は濁 $ろ^{20,21)}$ 。PNIPAM ブロックと温度に影響されずに水溶性 の AMPS ブロックからなる AB 型のブロック共重合体

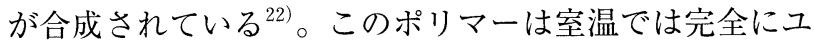
ニマー状態で溶解するが, 温度を上昇させると PNIPAM 鎖の会合により高分子ミセルを形成する。

\section{7 おわりに}

両親媒性高分子電解質は，増粘効果，分散効果，可溶 化効果などの実用的な特性を有することから，基礎と応 用の両面から活発な研究が進展しているが, ポリマーの 化学構造と自己組織化挙動との相関関係が完全に解明さ れたわけではない。それには, 分子量, 分子量分布, 連 鎖分布などの構造が精緻に制御された両親媒性高分子電 解質の合成法の確立が望まれる。今後, リビング重合な どの精密合成法を利用することで, 構造物性相関に関す る研究は益々盛んになるであろう。その結果，より高い 機能を持つ両親媒性高分子電解質や, 全く新しい刺激応 答性ポリマーの出現を期待したい。

\section{文献}

1) M. Almgren, P. Bahadur, M. Jansson, P. Li, W. Brown \& A. Bahadur, J. Colloid Interface Sci., 151, 157 (1991).

2) R. Xu, M.A. Winnik, G. Riess, B. Chu \& M.D. Croucher, Macromolecules, 25, 644 (1992).

3) J. Zhu, R.B. Lennox \& A. Eisenberg, Macromolecules, 26, 7339 (1993).

4) T. Noda, A. Hashidzume \& Y. Morishima, Langmuir, 16, 5324 (2000).

5) T. Noda, A. Hashidzume \& Y. Morishima, Langmuir, 17, 5984 (2001).

6) T. Noda, A. Hashidzume \& Y. Morishima, Polymer, 42, $9243(2000)$.

7) Y. Morishima, Bio-Industry, 12, 20 (1995).

8) Y. Morishima, TRIP, 2, 31 (1994).

9) Y. Morishima, In Multidimensional Spectroscopy of polymers; ACS Symposium Series 598; ACS, Washington DC, p. 490 (1995).

10) Y. Morishima, S. Nomura, M. Seki, T. Ikeda \& M. Kamachi, Macromolecules, 28, 2874 (1995).

11) Y. Morishima, M. Tsuji, M. Seki \& M. Kamachi, Macromolecules, 26, 3299 (1993).

12) S. Yusa, A. Sakakibara, T. Yamamoto \& Y. Morishima, Macromolecules, 35, 5243 (2002).

13) S. Yusa, A. Sakakibara, T. Yamamoto \& Y. Morishima, Macromolecules, 35, 10182 (2002).

14) K. Kalyanasundaram \& J.K. Thomas, J. Am. Chem. 
Soc., 99, 2039 (1977).

15) P.N. Hurter \& T.A. Hatton, Langmuir, 8, 5300 (1992).

16) K. Kataoka, G.S. Kwon, M. Yokoyama, T. Okano \& Y. Sakaurai, J. Controlled Release, 24, 119 (1993).

17) J. Chiefari, Y.K. Chong, F. Ercole, J. Krstina, T.P. Le, R.T.A. Mayadunne, G.F. Meijs, G. Moad, C.L. Moad, E. Rizzardo \& S.H. Thang, Macromolecules, 31, 5559 (1998).

18) T.P. Le, G. Moad, E. Rizzardo \& S.H. Thang, PCT Int. Appl. Wo 98/01478, 1998.
19) S. Yusa, Y. Shimada, Y. Mitsukami, T. Yamamoto \& Y. Morishima, Macromolecules, 36, 4208 (2003).

20) M. Heskins \& J.E. Guillet, Macromol. Sci., A2, 1441 (1991).

21) K. Kubota, S. Fujishige \& I. Ando, J. Phys. Chem., 94, 5154 (1990).

22) S. Yusa, Y. Shimada, Y. Mitsukami, T. Yamamoto \& Y. Morishima, Macromolecules, 37, 7507 (2004). 